\title{
Lingual dyskinesia in hyperthyroidism
}

\author{
Adlyne Reena Asirvatham, ${ }^{1}$ Karthik Balachandran, ${ }^{1}$ Shriraam Mahadevan, ${ }^{2,3}$ \\ Satishkumar Balasubramanian ${ }^{4}$
}

${ }^{1}$ Sri Ramachandra University Medical College, Chennai, India ${ }^{2}$ Endocrinology Department, Sri Ramachandra Medical College, Chennai, India

${ }^{3}$ Endocrinology, Endocrine and Speciality Clinic, Chennai, India ${ }^{4}$ Endocrinology, Diabetes and Metabolism, Sri Ramachandra University, Chennai, India

\section{Correspondence to} Dr Shriraam Mahadevan mshriraam@gmail.com

\section{Vovember 2017}

CrossMark

To cite: Asirvatham AR,

Balachandran K

Mahadevan S, et al. BMJ

Case Rep Published Online

First: [please include Day

Month Year]. doi:10.1136

bcr-2017-223226

\section{DESCRIPTION}

A 28-year-old female presented to the hospital with a 3-month history of palpitation, weight loss and neck swelling. On examination, she had diffuse soft goitre, warm extremities and fine tremors of hands. In addition, she had an irregular jerky lingual and lip movements suggestive of dyskinesia (see online supplementary video). There were no signs of infiltrative ophthalmopathy or dermopathy. Neurological examination was otherwise unremarkable. A clinical diagnosis of Graves' disease was made that was biochemically confirmed by elevated $\mathrm{T} 3$ and $\mathrm{T} 4$

\section{Learning points}

- Thyrotoxicosis may occasionally be associated with unusual neurological manifestations like lingual dyskinesia.

- Reversible and easily treatable conditions like hyperthyroidism should be kept in mind before investigating in detail for abnormal tongue movements. with suppressed tyroid stimulating hormone (TSH) as well as diffuse increased uptake of technetium in nuclear imaging. Unlike lingual tremors associated with other neurological conditions or adverse effects of drugs, thyrotoxicosis-associated lingual dyskinesia responds very well to beta blockers. ${ }^{1}$ After 6 months of follow-up on carbimazole and propranolol therapy, her thyrotoxicosis improved, and the abnormal tongue movements had disappeared.

Contributors ARA collected the case. KB contributed on manuscript preparation. SM made the diagnosis. SB recorded the video. All the authors were involved in literature search and reviewing the manuscript and its finalisation.

Competing interests None declared.

Patient consent Obtained.

Provenance and peer review Not commissioned; externally peer reviewed.

(C) BMJ Publishing Group Ltd (unless otherwise stated in the text of the article) 2017. All rights reserved. No commercial use is permitted unless otherwise expressly granted.

\section{REFERENCE}

1 Stasiolek M. Neurological symptoms and signs in thyroid disease. Thyroid Res 2015;8:A25.
Copyright 2017 BMJ Publishing Group. All rights reserved. For permission to reuse any of this content visit http://group.bmj.com/group/rights-licensing/permissions.

BMJ Case Report Fellows may re-use this article for personal use and teaching without any further permission.

Become a Fellow of BMJ Case Reports today and you can:

- Submit as many cases as you like

- Enjoy fast sympathetic peer review and rapid publication of accepted articles

- Access all the published articles

- Re-use any of the published material for personal use and teaching without further permission

For information on Institutional Fellowships contact consortiasales@bmjgroup.com

Visit casereports.bmj.com for more articles like this and to become a Fellow 